${ }^{1}$ Laboratory of Physiology and Pathophysiology, Centre for Preclinical Research and Technology (CePT), Medical University of Warsaw, Poland

²Department of Biophysics, Warsaw University of Life Sciences-SGGW, Warsaw, Poland

\title{
TTX-resistant sodium currents in medial prefrontal cortex pyramidal neurons depend on extracellular $\mathrm{Ca}^{2+}$ concentration
}

\author{
Corresponding author: \\ Ewa Nurowska, Laboratory \\ of Physiology and Pathophysiology \\ Centre for Preclinical Research and \\ Technology (CePT) Medical University \\ of Warsaw, Banacha 1b, \\ 02-097 Warsaw, Poland, \\ e-mail: ewa.nurowska@wum.edu.pl
}

Medical Research Journal 2019; Volume 4, Number 1, 35-40 DOI: 10.5603/MRJ.a2019.0008 Copyright (C 2019 Via Medica ISSN 2451-2591

\begin{abstract}
Background: Previous reports reported the presence of TTX-resistant Nav1.8 and Nav1.9 sodium channels in the cortex pyramidal neurons. A characteristic feature of Nav1.9 channels is activation at voltages close to $-70 \mathrm{mV}$. Therefore, they do not participate directly in the action potential but contribute to the regulation of the resting membrane potential. Their physiological role is modulation of cell excitability. The aim of the study was to investigate, with the use of patch clamp technique, the dependence of the activation thresholds of TTX-resistant sodium currents on the concentration of extracellular calcium in medial prefrontal cortex pyramidal neurons in rats.

Results: The recorded values of the threshold of the voltage-dependent sodium currents were in the range of $-65 \mathrm{mV}$ to $-75 \mathrm{mV}$. This suggests that the sodium currents may result from the presence of Nav1.9 channels in the rat pyramidal neurons. The threshold for the activation of sodium currents depended on the concentration of $\mathrm{Ca}^{2+}$. Increasing the concentration of calcium ions in the extracellular solution by $5 \mathrm{mM}$ caused the depolarizing shift in the activation potential by about $10 \mathrm{mV}$. The effect of calcium ion concentration on the potential of TTX-resistant currents activation suggests that Nav1.9 channels are modulated by extracellular $\mathrm{Ca}^{2+}$ concentration.

Conclusions: The study has experimentally confirmed that TTX-resistant channels are present in the cell membrane of the rat prefrontal cortex pyramidal neurons and may, therefore, take a physiological role in the conductivity of sodium currents in a manner dependent on the concentration of extracellular ions. Keywords: sodium currents TTX-resistant, Nav1.9 ion channel, pyramidal neurons, patch-clamp
\end{abstract}

Med Res J 2019; 4 (1): 35-40

\section{INTRODUCTION}

Sodium channels present in cell membranes enable sodium ions to flow into the cytoplasm, thus increasing the electric potential of the membrane or depolarization. This phenomenon is a key element of many physiological processes, one of the most important of which is generation and transmission of neural impulses, including those related to pain. Sodium channels comprise a varied group, with individual members having separate coding genes, their specific opening and closing kinetics, as well as location and physiological functions.

The voltage-gated $\mathrm{Na}_{\mathrm{v}} 1.9$ sodium channel is formed by an $\alpha$ subunit coded by the SCN11A gene. It is preferentially expressed in neurons of dorsal root ganglia (DRG), trigeminal ganglion neurons and in the enteric nervous system [1, 2]. The relation between $\mathrm{Na}_{v} 1.9$ channels and pain is confirmed by cases of people with mutations of this channel, suffering from neuropathic pain [3, 4]. Mutations of this channel caused depolarization of resting potential of neurons, facilitating spontaneous generation of action potentials. On the other hand, mutations of this channel were also found in people who did not perceive pain e.g. upon fractures or injuries [5]. $\mathrm{Na}_{\mathrm{v}} 1.9$ channels are activated at the potential of approximately $-70 \mathrm{mV}$, which is lower than activation potential for other voltage-gated sodium channels, are inactivated slowly, i.e. the sodium current disappears slowly over the duration of the activating stimulus and is resistant to TTX (tetrodotoxin), a blocker of most voltage-gated sodium channels. Because of this characteristic, it is thought that $\mathrm{Na}_{\mathrm{v}} 1.9$ channels 
regulate the excitability of pain receptors and are an important element in the transmission of pain signals to the central nervous system $[1,6]$.

It was accepted until recently that $\mathrm{Na}_{\mathrm{v}} 1.9$ channels are absent in the central nervous system [7], however, the presence of the $\mathrm{Na}_{\mathrm{v}} 1.9$ protein was proven in pyramidal neurons of the $\mathrm{V}$ layer of prefrontal cortex in rats using confocal microscopy and $\mathrm{Na}_{\mathrm{v}} 1.9$ antibody labelling $[8,9]$. Previous studies showed that TTX-resistant sodium current in pyramidal neurons of rat cortex displays characteristics typical for Nav1.8 and Nav1.9 channels $[9,10]$. Thus, depending on the patch clamp protocol used, it may be a result of currents from both these channels. The Nav1.9 channel probably impacts the membrane potential of pyramidal cells because of the fact that its activation potential is close to the resting potential of the cell [8]. The goal of this work was to study the influence of extracellular calcium on the activation threshold of TTX-resistant sodium currents in such cells using the patch clamp technique. This means that the study of calcium influence on TTX-resistant currents, a component of which includes currents conducted by the Nav1.9 channel is a study on the mechanism in which calcium regulates the excitability of pyramidal cells.

Under physiological conditions, the concentration of calcium in blood varies in the range between $2.25 \mathrm{mM}$ and $2.75 \mathrm{mM}$. Approximately half of the calcium exists in a free ionized form. The influence of chances to calcium concentration on the excitability of the nervous system is proven by symptoms related to hypo- and hypercalcemia. There are many typical, neurological symptoms of hypocalcemia. Typical symptoms include tingling, tetany and muscle contractions. Severe hypocalcemia may cause seizures [11-16] or be responsible for the paradoxical reaction (seizure intensification) to phenytoin administered as an anti-seizure medication [17]. Neurological and neuromuscular symptoms of hypercalcemia yield a different clinical picture and include changes such as drowsiness, coma, decreased muscle strength, adynamia or periodic muscle paralysis [18]. The listed symptoms indicate that hypocalcemia is the cause of symptoms related to neuromuscular hyperexcitability, while hypercalcemia is the cause of decreased neuronal or neuromuscular excitability. Mechanisms responsible for increased excitability of the nervous system in hypocalcemia or for decreased excitability in hypercalcemia are not fully known [19].

Studies performed on brain slices indicate that a decrease of calcium concentration in the extracellular solution stimulates spontaneous neural activity. It was shown that pre-incubation of samples in a solution with low calcium concentration in the presence of synaptic transmission inhibitors results in spontaneous nonsynaptic epileptiform activity, increased resting potential of the cells and a decrease of the action potential activation threshold [20-22]. On the contrary, pre-incubation of brain slices in a solution with increased calcium concentration inhibits spontaneous neural activity caused by the increased $\mathrm{K}^{+}$concentration [23]. These observations indicate that calcium regulates the activity of ion channels engaged in the determination of resting potential and of channels responsible for action potential generation. In this work, we have studied if and how an increase of extracellular calcium concentration influences the activation potential of TTX-resistant currents. The study was performed on freshly isolated and enzymatically/mechanically dispersed pyramidal neurons of the rat medial prefrontal cortex [24].

\section{Material and methods}

The study was performed on slices of the medial prefrontal cortex of 3 weeks old male Wistar rats. After application of anaesthesia using ethyl chloride and decapitation, the brain was placed in liquid cooled down to $0^{\circ} \mathrm{C}$, with the following composition $(\mathrm{mM})$ : saccharose 234, HEPES 15, glucose 11, $\mathrm{MgSO}_{4} 4$, $\mathrm{KCl} 2.5$, ascorbic acid 1, $\mathrm{NaH}_{2} \mathrm{PO}_{4} 1$. The part of the brain containing frontal lobes was cut into $300 \mu \mathrm{m}$ thick slices in a vibratome and placed in a liquid kept at room temperature, with the following composition $(\mathrm{mM}): \mathrm{NaCl} 118, \mathrm{NaHCO}_{3} 25$, glucose 6, $\mathrm{MgSO}_{4} 3$, $\mathrm{KCl} 2.5, \mathrm{NaHPO}_{4} 1,25, \mathrm{CaCl}_{2}$ 0,5, glutathione 0.01, saturated with carbogen $\left(95 \% \mathrm{O}_{2}, 5 \% \mathrm{CO}_{2}\right)$. The slices were incubated in this solution for 1-6 hours. In order to isolate individual pyramidal neurons, the slices were placed in a solution with the following composition $(\mathrm{mM})$ : sodium isothioate 140 , glucose 20 , HEPES 15 , $\mathrm{MgCl}_{2} 4, \mathrm{KCl} 2, \mathrm{CaCl}_{2}$, a part of the prefrontal cortex was cut out and subjected to enzymatic activity in the same liquid containing added protease $(20 \mu \mathrm{g} / 20 \mathrm{ml})$ for 20 minutes at $33-37^{\circ} \mathrm{C}$. Parts of the prefrontal cortex were mechanically dispersed using a glass pipette. The cell suspension was placed in a patch clamp recording chamber, on a glass pre-coated with Poly-L-lysine (Sigma-Aldrich). Electrophysiological tests were performed after approximately 5 minutes.

The functional study of TTX-resistant channels used the patch clamp technique in the whole-cell configuration, which enables recording of currents from the whole cell. The research setup included an Axopatch 1D amplifier, a digital-analog converter Digidata 1440A, a computer and a reverse microscope Olympus IX71. The pClamp10 program (Molecular Devices, USA) was used to record and analyse the data. A silver chloride measurement electrode was placed inside a pipette containing solution with the following composition (mM): CsF 110, $\mathrm{CsCl} 20, \mathrm{NaCl}$ 
10, HEPES 10, $\mathrm{MgCl}_{2}$ 2, EGTA 2. The extracellular solution included $(\mathrm{mM})$ : $\mathrm{NaCl} 130$, TEA-Cl 30, HEPES $10, \mathrm{MgCl}_{2} 2, \mathrm{CaCl}_{2} 1,5,4 \mathrm{AP} 1, \mathrm{CdCl}_{2}$ 0.1. This solution was replaced in individual experiments with an identical liquid containing TTX $(0.5 \mu \mathrm{M})$ or:

A) a solution with low sodium ion concentration, in which the control $130 \mathrm{mM} \mathrm{NaCl}$ was replaced with a mixture of $10 \mathrm{mM} \mathrm{NaCl}$ and $120 \mathrm{mM}$ choline,

B) an extracellular solution with increased $\mathrm{Ca}^{2+}$ concentration of $6.5 \mathrm{mM}$ and $\mathrm{CdCl}_{2}$ concentration of $0.2 \mathrm{mM}$. All solutions, in which currents were recorded contained $\mathrm{CdCl}_{2}$ and, if TTX-resistant currents were recorded, also $0.5 \mu \mathrm{M}$ TTX. Cadmium was added in order to block calcium channels.

Once a high resistance connection was established between the measurement pipette and the cell membrane („giga seal”), the membrane was ruptured and if the resistance of the connection between the pipette and the cell and pipette resistance were satisfactory (> $300 \mathrm{M} \Omega$ and $<10 \mathrm{M} \Omega$, respectively), cellular currents were recorded. In order to record the current, a linearly increased potential in the range between $-110 \mathrm{mV}$ and $80 \mathrm{mV}$ and with the slope of $0.25 \mathrm{mV} / \mathrm{ms}$ was applied to the cell membrane. The potential value between recordings was maintained at $-70 \mathrm{mV}$. A brief $(500 \mathrm{~ms})$ potential impulse of $-110 \mathrm{mV}$ was applied before the recording in order to remove the inactivation of sodium channels. All measurements were performed at room temperature.

Before the analysis of TTX-resistant currents, the linear component corresponding to leak current was subtracted from the recorded current, Fig. 1.

The statistical analysis employed:

C) the Shapiro-Wilk test and the Kolmogorov-Smirnov test in order to verify the hypothesis of conformity of the distribution of the studied characteristics with a normal distribution;

D) the $t$-Student test for dependent samples in order to verify the hypothesis of statistically significant differences between the $\mathrm{I}_{\max }$ and $\mathrm{V}_{\text {act }}$ values recorded under different experimental conditions;

E) Wilcoxon signed-rank test, in order to verify the hypothesis of significant differences between the recorded values, if the distribution of the tested characteristic did not conform to a normal distribution;

The analysis was performed on current recordings performed on 13 pyramidal neurons obtained from 5 rats.

\section{Results}

The tested cells displayed intracellularly oriented currents, some of which were resistant to TTX (Fig. 2A).

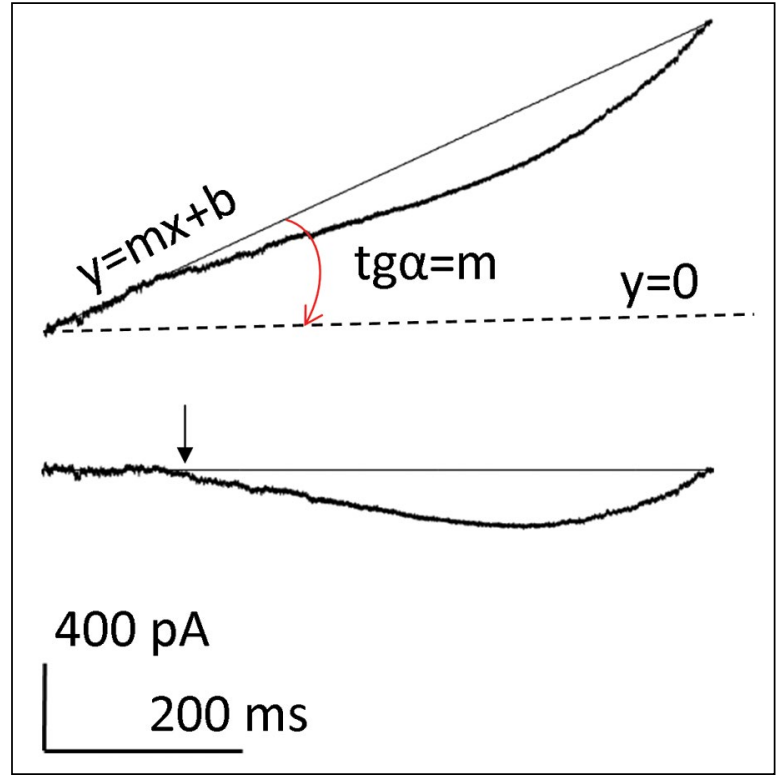

Figure 1. Voltage ramp (from-110 mV to $60 \mathrm{mV}$ ) was applied to evoke sodium currents. The leak currents were fitted by a line to the portion of the current that was more negative than $-80 \mathrm{mV}$ and then subtracted. The arrow indicates the threshold of the voltage-dependent component of the inward current.

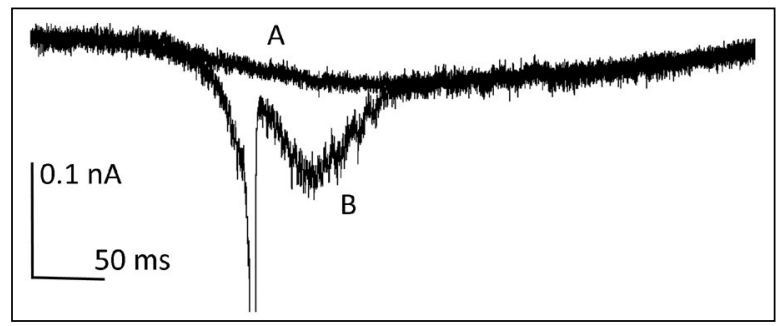

Figure 2. The effect of TTX on the sodium currents. Voltage ramp: from $-75 \mathrm{mV}$ (left) to $30 \mathrm{mV}$ (right). $\mathrm{A}-0.5 \mu \mathrm{M}$ TTX, B - no TTX added.

If TTX was absent in the extracellular solution, the recordings showed quickly activated and inactivated sodium currents characteristic for action potentials and slowly activated and inactivated currents susceptible to TTX (Fig. 2B).

TTX-resistant currents depended on the concentration of sodium ions (Fig. 3). The extracellular solution with low $\mathrm{Na}^{+}$concentration (choline was the main cation in the solution) showed an amplitude of the peak TTX-resistant current $\left(I_{\max }\right)$ lower than in the control solution (30.8 \pm 10.5 pA vs. $87.7 \pm 15.5$ pA, respectively, $n=13$, $p<0.05)$. The activation potential of the TTX-resistant current $\left(\mathrm{V}_{\mathrm{act}}\right)$ was $-74.8 \pm 2.0 \mathrm{mV}$ in the control solution. 


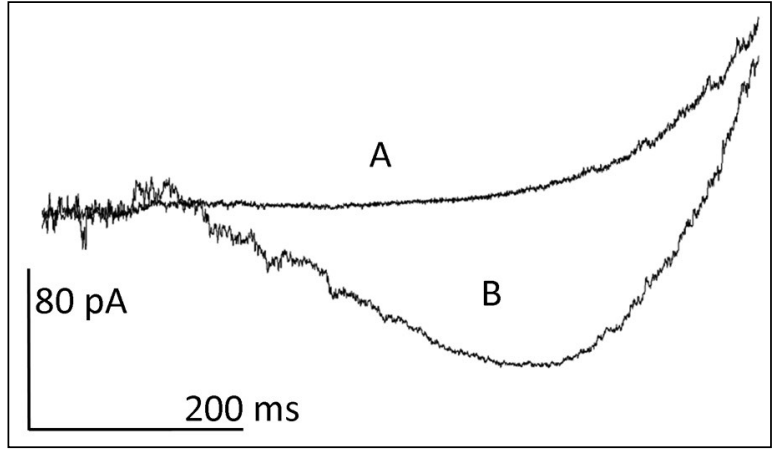

Figure 3. The effect of reducing the sodium concentration on the recorded currents. Voltage ramp: from $-110 \mathrm{mV}$ (left) to $60 \mathrm{mV}$ (right). A $-10 \mathrm{mM} \mathrm{Na}$; $\mathbf{B}-130 \mathrm{mM}$ $\mathrm{Na}+$. TTX $(0,5 \mu \mathrm{M})$ was present in $\mathrm{A}$ and $\mathrm{B}$.

The TTX-resistant solution was characterised by slow activation and slow inactivation.

An increase of the extracellular $\mathrm{Ca}^{2+}$ concentration from 1.5 to $6.5 \mathrm{mM}$ did not result in statistically significant differences in the values of the peak current $I_{\max }$ $(63.2 \pm 23.5$ pA vs. $96.0 \pm 51.9$ pA, $n=6, p>0.5)$, but it influenced the activation potential significantly. The activation potential was: $-69.0 \pm 3.5 \mathrm{mV}$ for the control sample and $-59.0 \pm 3.4 \mathrm{mV}$ for $6.5 \mathrm{mM} \mathrm{Ca}^{2+}$. An increase of the $\mathrm{Ca}^{2+}$ concentration by $5 \mathrm{mM}$ resulted in a statistically significant ( $t$-Student test for dependent samples, $n=6$, $p<0.05$ ) increase of the activation potential by $10 \mathrm{mV}$ on average, what constituted approximately $15 \%$ of the initial value of the activation potential. An increase of the $\mathrm{Ca}^{2+}$ concentration shifted the activation of the TTX-resistant current by $10 \mathrm{mV}$ towards less negative potential values on average, namely, channel activation required a more depolarised membrane.

Several attempts at recording sodium currents in calcium-free solution ( $0 \mathrm{mM} \mathrm{Ca}^{2+}, 0.1 \mathrm{mM}$ EGTA) were undertaken. Recording in calcium-free solution failed because of the quick loss of tightness of the pipette-cell seal at negative pipette potentials.

\section{Discussion}

The presented results show that in pyramidal neurons of the prefrontal cortex of rats are present currents which are: TTX-resistant, dependent on sodium ion concentrations, slowly activated and inactivated, with low activation potential. These features are characteristic for sodium current transmitted by the $\mathrm{Na}_{\mathrm{v}} 1.9$ channels [6]. Expression of TTX-resistant channels $\left(\mathrm{Na}_{\mathrm{v}} 1.9\right.$ and $\mathrm{Na}_{\mathrm{v}} 1.8$ ) and their activity (presence of TTX-resistant currents with different activation potentials) was already shown before in pyramidal neurons of the prefrontal cortex of rats [8-10]. Thus, our electrophysiological studies provide additional confirmation of the presence of functional, TTX-resistant channels with low activation potential in pyramidal cortex neurons of rats. So far, no proofs confirming the presence of these channels in the prefrontal human cortex are available.

The influence of extracellular calcium on activation of sodium channels is a phenomenon observed for voltage-gated sodium channels, sensitive to TTX [25]. The occurrence of a similar phenomenon in TTX-resistant channels indicates that the activity of calcium ions is non-specific.

The mechanism of extracellular calcium impact on sodium channels has not been clearly explained before. One of the proposed mechanisms is the mechanism in which the membrane potential is shielded by $\mathrm{Ca}^{2+}$ ions attracted to the membrane surface by negative membrane charges (e.g. hydrophilic phospholipids and membrane proteins). This mechanism was proposed by Hill $[26,27]$. In the case of the proposed mechanism, calcium ions disrupt the operation of the sodium channel membrane potential sensors through neutralization/shielding of membrane anionic groups. However, this mechanism has not been confirmed in studies on the functioning of potassium delayed rectifier $\mathrm{K}_{\mathrm{DR}}$ channels [26]. The cited work showed that extracellular calcium does not influence the functioning of the $\mathrm{K}_{\mathrm{DR}}$ channels. Thus, screening of the potential by calcium ions would not apply to the aforementioned channel and it should be a mechanism equally applicable to $\mathrm{Na}^{+}$ and $\mathrm{K}^{+}$channels. A different action mechanism was proposed for $\mathrm{Ca}^{2+}$ ions by Armstrong and Cot [28]. They suggested that calcium binds to the channel protein with affinity different in the case of open and closed channel. If the closed channel shows higher affinity to $\mathrm{Ca}^{2+}$ than the open channel, a transition between the closed and the open state would be more difficult if calcium binds to the channel. At high calcium concentrations, this would result in a shift of the activation threshold towards depolarization. This model was confirmed for selected channels in studies by Boccaccio et al. [25]. It seems, however, that more studies should be performed to verify the described models.

Despite the fact that we are unable to specify the mechanism of calcium activity influencing TTX-resistant sodium channels, we showed that these are currents susceptible to the concentration of extracellular calcium. A calcium concentration increase of $5 \mathrm{mM}$ results in a shift of the activation potential towards depolarization by $10 \mathrm{mV}$.

Sodium channels with low activation threshold potentials and slow inactivation do not play a significant role in the conduction of activation potential, however, they are important in the regulation of resting potential and influence cell excitability [6]. The significance of the influence of the observed shift in the activation 
threshold of TTX-resistant currents should be explained in studies on the influence of calcium on the resting potential of cells. The resting potential is determined with a significant contribution of other channels, mainly potassium leak channels. It is known that intracellular calcium blocks some of such channels [29]. In addition to the leak potassium channels, sodium leak channels (NALCN) also influence membrane potential. These channels are blocked by extracellular calcium in a G-protein dependent mechanism [30].

Prefrontal cortex plays an important role in planning, initiating and controlling undertaken activities. This area participates on attention focusing and is responsible for working memory [31]. This is confirmed by studies on animals which indicate, that prefrontal cortex neurons control fear-related memory, natural fear and working memory [32-34]. Functional disruptions of the prefrontal cortex are observed in neuropsychiatric conditions, such as depression [35], bipolar disorder [36], anxiety [37], anti-social behaviour disorders [38] and schizophrenia. $\mathrm{Na}_{v} 1.9$ channels could influence prefrontal cortex functions through the influence on neural excitability. The presented study contributes to future studies on mechanisms controlling the activity of TTX-resistant channels in the central nervous system. It also indicates that TTX-resistant currents in DRG neurons may also be regulated by the concentration of extracellular calcium.

\section{Conclusions}

The experimental study confirmed that TTX-resistant channels are present in cell membranes of pyramidal neurons of the medial prefrontal cortex of rats and may thus play a physiological role in the transmission of sodium currents dependent on the concentration of calcium ions in the extracellular solution.

\section{References}

1. Dib-Hajj SD, Black JA, Waxman SG. NaV1.9: a sodium channel linked to human pain. Nat Rev Neurosci. 2015; 16(9): 511-519, doi: 10.1038/nrn3977, indexed in Pubmed: 26243570.

2. Fang $X$, Djouhri L, Black JA, et al. The presence and role of the tetrodotoxin-resistant sodium channel $\mathrm{Na}(\mathrm{v}) 1.9$ ( $\mathrm{NaN}$ ) in nociceptive primary afferent neurons. J Neurosci. 2002; 22(17): 7425-7433, doi: 10.1523/jneurosci.22-17-07425.2002, indexed in Pubmed: 12196564.

3. Hockley JRF, Winchester WJ, Bulmer DC. The voltage-gated sodium channel NaV 1.9 in visceral pain. Neurogastroenterol Motil. 2016; 28(3): 316-326, doi: 10.1111/nmo.12698, indexed in Pubmed: 26462871.

4. Huang J, Han C, Estacion M, et al. PROPANE Study Group. Gain-of-function mutations in sodium channel $\mathrm{Na}(\mathrm{v}) 1.9$ in painful neuropathy. Brain. 2014; 137(Pt 6): 1627-1642, doi: 10.1093/brain/awu079, indexed in Pubmed: 24776970.

5. Phatarakijnirund V, Mumm S, McAlister WH, et al. Congenital insensitivity to pain: Fracturing without apparent skeletal pathobiology caused by an autosomal dominant, second mutation in SCN11A encoding volta- ge-gated sodium channel 1.9. Bone. 2016; 84: 289-298, doi: 10.1016/J. bone.2015.11.022, indexed in Pubmed: 26746779.

6. Herzog RI, Cummins TR, Waxman SG. Persistent TTX-resistant Na+ current affects resting potential and response to depolarization in simulated spinal sensory neurons. J Neurophysiol. 2001; 86(3): 1351-1364, doi: 10.1152/jn.2001.86.3.1351, indexed in Pubmed: 11535682.

7. Cardoso FC, Lewis RJ. Sodium channels and pain: from toxins to therapies. Br J Pharmacol. 2018; 175(12): 2138-2157. doi: 10.1111/bph.13962, indexed in Pubmed: 28749537.

8. Kurowski P, Gawlak M, Szulczyk P. Muscarinic receptor control of pyramidal neuron membrane potential in the medial prefrontal cortex (mPFC) in rats. Neuroscience. 2015; 303: 474-488, doi: 10.1016/j. neuroscience.2015.07.023, indexed in Pubmed: 26186898.

9. Gawlak M, Szulczyk B, Berłowski A, et al. Age-dependent expression of Nav1.9 channels in medial prefrontal cortex pyramidal neurons in rats. Dev Neurobiol. 2017; 77(12): 1371-1384, doi: 10.1002/dneu.22537, indexed in Pubmed: 28913981.

10. Szulczyk B, Nurowska E. Valproic acid inhibits TTX-resistant sodium currents in prefrontal cortex pyramidal neurons. Biochem Biophys Res Commun. 2017; 491(2): 291-295, doi: 10.1016/j.bbrc.2017.07.109, indexed in Pubmed: 28739252

11. Erdeve $\mathrm{O}$, Atasay $\mathrm{B}$, Arsan $\mathrm{S}$, et al. Hypocalcemic seizure due to congenital rickets in the first day of life. Turk J Pediatr. 2007; 49(3): 301-303, indexed in Pubmed: 17990585.

12. Tsai PL, Lian LM, Chen WH. Hypocalcemic seizure mistaken for idiopathic epilepsy in two cases of DiGeorge syndrome (chromosome 22q11 deletion syndrome). Acta Neurol Taiwan. 2009; 18(4): 272-275, indexed in Pubmed: 20329596.

13. Milman S, Epstein EJ. Proton pump inhibitor-induced hypocalcemic seizure in a patient with hypoparathyroidism. Endocr Pract. 2011; 17(1): 104-107, doi: 10.4158/EP10241.CR, indexed in Pubmed: 21041166

14. El Asri AC, Akhaddar A, Baallal H, et al. Hypocalcemic seizure in adult: rare cause of lumbar fracture. Clin Neurol Neurosurg. 2012; 114(6): 738-740, doi: 10.1016/j.clineuro.2011.12.015, indexed in Pubmed: 22280986

15. Kidwell KS, Kopp WE, Albano EA, et al. J Pediatr Hematol Oncol. 2014; 36(4): 305-307, doi: 10.1097/MPH.0b013e318282d99c, indexed in Pubmed: 23426003

16. Korkmaz HA, Dizdarer C, Ecevit CO. Hypocalcemic seizure in an adolescent with Down syndrome: a manifestation of unrecognized celiac disease. Turk J Pediatr. 2013; 55(5): 536-538, indexed in Pubmed: 24382537.

17. Ali FE, Al-Bustan MA, Al-Busairi WA, et al. Loss of seizure control due to anticonvulsant-induced hypocalcemia. Ann Pharmacother. 2004; 38(6) 1002-1005, doi: 10.1345/aph.1D467, indexed in Pubmed: 15084684

18. Kokot F. Zaburzenia Gospodarki Wodno-Elektrolitowej i Kwasowo-Zasadowej. PZWL, Wydanie II, Warszawa. ; 2007.

19. Han P, Trinidad BJ, Shi J. Hypocalcemia-induced seizure demystifying the calcium paradox. ASN Neuro. 2015; 7(2) doi: 10.1177/1759091415578050, indexed in Pubmed: 25810356.

20. Roper SN, Obenaus A, Dudek FE, et al. Osmolality and nonsynaptic epileptiform bursts in rat CA1 and dentate gyrus. Ann Neurol. 1992; 31 (1): 81-85, doi: 10.1002/ana.410310115, indexed in Pubmed: 1543352.

21. Bikson M, Baraban SC, Durand DM. Conditions sufficient for nonsynaptic epileptogenesis in the CA1 region of hippocampal slices. J Neurophysiol. 2002; 87(1): 62-71, doi: 10.1152/jn.00196.2001, indexed in Pubmed: 11784730

22. Wang T, Wang J, Cottrell JE, et al. Small physiologic changes in calcium and magnesium alter excitability and burst firing of CA1 pyramidal cells in rat hippocampal slices. J Neurosurg Anesthesiol. 2004; 16(3): 201-209, doi: 10.1097/00008506-200407000-00004, indexed in Pubmed: 15211157

23. Isaev D, Ivanchick $G$, Khmyz V, et al. Surface charge impact in low-magnesium model of seizure in rat hippocampus. J Neurophysiol. 2012; 107(1): 417-423, doi: 10.1152/jn.00574.2011, indexed in Pubmed: 22031777.

24. Sławińska K. Charakterystyka prądów TTX-opornych w neuronach piramidowych kory przedczołowej szczura. Praca magisterska. Warszawski Uniwersytet Medyczny. 2016.

25. Boccaccio A, Moran O, Conti F. Calcium dependent shifts of $\mathrm{Na}+$ channel activation correlated with the state dependence of calcium-binding to the pore. Eur Biophys J. 1998; 27(6): 558-566, doi: 10.1007/s002490050166, indexed in Pubmed: 9791938.

26. Hille B. Charges and potentials at the nerve surface. Divalent ions and pH. J Gen Physiol. 1968; 51(2): 221-236, doi: 10.1085/jgp.51.2.221, indexed in Pubmed: 5641636.

27. Hille B, Woodhull AM, Shapiro BI. Negative surface charge near sodium channels of nerve: divalent ions, monovalent ions, and 
pH. Philos Trans R Soc Lond B Biol Sci. 1975; 270(908): 301-318, doi: 10.1098/rstb.1975.0011, indexed in Pubmed: 238230.

28. Armstrong CM, Cota G. Calcium ion as a cofactor in Na channel gating. Proc Natl Acad Sci U S A. 1991; 88(15): 6528-6531, doi: 10.1073/pnas.88.15.6528, indexed in Pubmed: 1650473.

29. Enyeart JJ, Liu H, Enyeart JA. Calcium-dependent inhibition of adrenal TREK-1 channels by angiotensin II and ionomycin. Am J Physiol Cell Physiol. 2011; 301(3): C619-C629, doi: 10.1152/ajpcell.00117.2011, indexed in Pubmed: 21613605.

30. Lu B, Zhang Qi, Wang H, et al. Extracellular calcium controls background current and neuronal excitability via an UNC79-UNC80-NALCN cation channel complex. Neuron. 2010; 68(3): 488-499, doi: 10.1016/j. neuron.2010.09.014, indexed in Pubmed: 21040849.

31. Riley M, Constantinidis C. Role of Prefrontal Persistent Activity in Working Memory. Frontiers in Systems Neuroscience. 2016; 9 , doi: 10.3389/fnsys.2015.00181.

32. Peters J, Kalivas PW, Quirk GJ. Extinction circuits for fear and addiction overlap in prefrontal cortex. Learn Mem. 2009; 16(5): 279-288, doi: 10.1101/Im.1041309, indexed in Pubmed: 19380710 .

33. Ohashi M, Saitoh A, Yamada M, et al. Activation of the prelimbic medial prefrontal cortex induces anxiety-like behaviors via N-Methyl-
-D-aspartate receptor-mediated glutamatergic neurotransmission in mice. J Neurosci Res. 2014; 92(8): 1044-1053, doi: 10.1002/jnr.23391, indexed in Pubmed: 24752881

34. Goldman-Rakic PS. The physiological approach: Functional architecture of working memory and disordered cognition in schizophrenia. In: Goldman-Rakic PS. ed. Biological Psychiatry.Vol 46. 1999: 650-661 .

35. Jaracz J. Anatomia depresji w świetle wyników badań neuroobrazowych. Psychiatr Pol. 2008; 42(6): 875-888.

36. Kałwa A. Zaburzenia funkcji poznawczych w chorobie afektywnej dwubiegunowej. Psychiatr Pol. 2011; 45(6): 901-910.

37. Lehner M, Wisłowska-Stanek A, Plaznik A. Wygaszanie reakcji emocjonalnej jako nowy cel farmakoterapii zaburzeń lękowych. Psychiatr Pol. 2009; 43(6): 639-653.

38. Radochoński M, Perenc ARA. Neurobiologiczne uwarunkowania antyspołecznych zaburzeń zachowania. Przegląd Med Uniw Rzesz. 2009: 4: 405-410.

39. Negrón-Oyarzo I, Lara-Vásquez A, Palacios-García I, et al. Schizophrenia and reelin: a model based on prenatal stress to study epigenetics, brain development and behavior. Biol Res. 2016; 49: 16, doi: 10.1186/s40659-016-0076-5, indexed in Pubmed: 26968981. 